\title{
7
}

\section{Tick-Borne Encephalitis Virus: A General Overview}

\author{
Oliver Donoso-Mantke ${ }^{1}$, Luidmila S. Karan² and Daniel Růžek ${ }^{3}$ \\ ${ }^{1}$ German Consultant Laboratory for Tick-borne Encephalitis, \\ Robert Koch Institute, Berlin, \\ ${ }^{2}$ Laboratory of Epidemiology of Zoonoses, Central Research Institute of Epidemiology, \\ Moscow, \\ Institute of Parasitology, Biology Centre of the Czech Academy of Sciences, \\ České Budějovice, \\ ${ }^{1}$ Germany \\ ${ }^{2}$ Russia \\ ${ }^{3}$ Czech Republic
}

\section{Introduction}

Tick-borne encephalitis (TBE) virus is classified as one species with three subtypes, namely the European subtype, the Siberian subtype and the Far Eastern subtype. TBE is distributed in an endemic pattern of so-called natural foci over a wide geographical area from Western Europe to the northern part of Japan. It is the most important flavivirus infection of the central nervous system in Europe and Russia, with about 13,000 estimated human cases per year. The epidemiology of TBE is closely related to the ecology and biology of ixodid ticks. In nature, TBE virus is propagated in a cycle involving permanently infected ticks and wild vertebrate hosts. Currently, the diagnosis of TBE is mainly based on the detection of specific antibodies in serum and cerebrospinal fluid. No specific treatment for the disease is available to date, but it can be prevented by active immunization.

\section{Ecology of TBE virus}

According to the concept of Pavlovskij, TBE virus is maintained in a cycle involving ticks and wild vertebrate animals in forested natural foci under certain botanical, zoological, climatical and geo-ecological conditions (Pavlovskij, 1939). The development of a TBE natural focus depends on the coincidence of all these factors.

The principal carrier (vector) as well as the reservoir of the European TBE virus subtype is the tick Ixodes ricinus (Rampas and Gallia, 1949), a dominant hard tick across Europe. However, the virus has been isolated also from several other tick species (Grešíková and Nosek, 1966; Křivanec et al., 1988; Grešíková and Kaluzová, 1997). I. ricinus ticks live preferentially in the dense undergrowth of the forests where the relative humidity is high. Oak, hornbeam as well as beech and fir woods with rich undergrowth of weeds, ferns, elder, hazel, and bramble bushes provide an ideal habitat for these ticks (Süss, 2003). 
TBE virus strains from Far Eastern and Siberian subtypes are transmitted predominantly by I. persulcatus. This tick, which aggressively attaches to humans, comprises $80-97 \%$ of all tick species in the Ural, Siberia and the Far East region of Russia (Gritsun et al., 2003a). The habitat of $I$. persulcatus is mainly distributed in different taiga forest types. Key factors affecting I. persulcatus ticks are relatively warm and humid climate conditions. In the event of high humidity the ticks are frequent in warm and drained spruce and small-leaved forests. Under low humidity and warm conditions, the ticks are frequent in broad-leaved coniferous forests and in shaded places. The natural (boreal) habitat of I. persulcatus ticks spreads from the Baltic States to the Pacific. On the border of habitats (Baltic States, Finland, Karelia, and several regions of the European part of Russia) sympatric habitations of $I$. persulcatus and I. ricinus were observed (Votiakov et al., 2002).

The TBE natural foci do not expand beyond the natural habitats. However, TBE virus has been isolated also from 18 other tick species in Russia (e.g. frequently from Dermacentor marginatus in some steppe regions), but sporadically also from other parasitic invertebrates, e.g. fly, flea and lice (Gritsun et al., 2003b).

The life cycle of ticks (Fig. 1) consists of three stages: the larva, nymph and adult. Each stage feeds on a different individual vertebrate host, usually for a period of a few days. E.g., the infection rate of fed adult ticks and their immediate progenies depends on the bigger mammalian hosts: cattle and wild hares, foxes, boars and deer. Therefore, these hosts are of primary importance for the existence and transmission of TBE virus.

Each stage of $I$. ricinus takes approximately one year to develop to the next stage. Thus, the shortest life cycle takes 3 years on average to complete. However, it may vary from 2 to 6 years throughout the geographical range, depending on the availability of hosts and climatic conditions (Süss, 2003). Following copulation, the female spends six to eleven days feeding on blood and, during subsequent months, deposits 500 to 5,000 eggs. Several weeks later, larvae measuring $0.6-1.0 \mathrm{~mm}$ hatch from the eggs. The molting occurs only twice. Six-legged larva develops into an eightlegged nymph, which in turn molts to produce a similar but larger adult (Süss, 2003). TBE virus can be transmitted to man or other hosts by all the tick stages, i.e. larvae, nymphs, as well as adult ticks.

The virus infects ticks chronically for the duration of their life. Nevertheless, ticks themselves do not develop the disease. The virus is transmitted from one developmental stage of the tick to the next (transstadial transmission). In the period that precedes molting, the virus multiplies in the tick and invades almost all the tick's organs (Benda, 1958). TBE virus can be also transmitted transovarially (from infected fertilized female to egg) (Benda, 1958) and during co-feeding of ticks on the same host (Labuda et al., 1993; 1997). Despite the fact that the percentage of transovarial transmission of members of the European TBE virus subtype in I. ricinus is much lower than of Siberian and Far Eastern strains in I. persulcatus, it is sufficient under certain conditions to ensure the continuity of virus population. Cofeeding of both infected and naïve ticks on the same host allows TBE virus transmission even in the absence of systemic viremia. Results from laboratory experiments suggested that in this case viremia could be a product, rather than a prerequisite, of TBE virus transmission (Labuda et al., 1997). Frequently, it is observed that different stages of ticks belonging to various generations feed on the same host. Therefore, the virus is transmitted efficiently between generations of carriers for at least 5 consecutive years (Korenberg et al., 1991).

The prevalence of TBE virus infected I. ricinus ticks varies from $0.5 \%$ to $5 \%$, whereas in $I$. persulcatus in certain regions of Russia prevalence up to $40 \%$ was recorded (Charrel et al., 2004). 


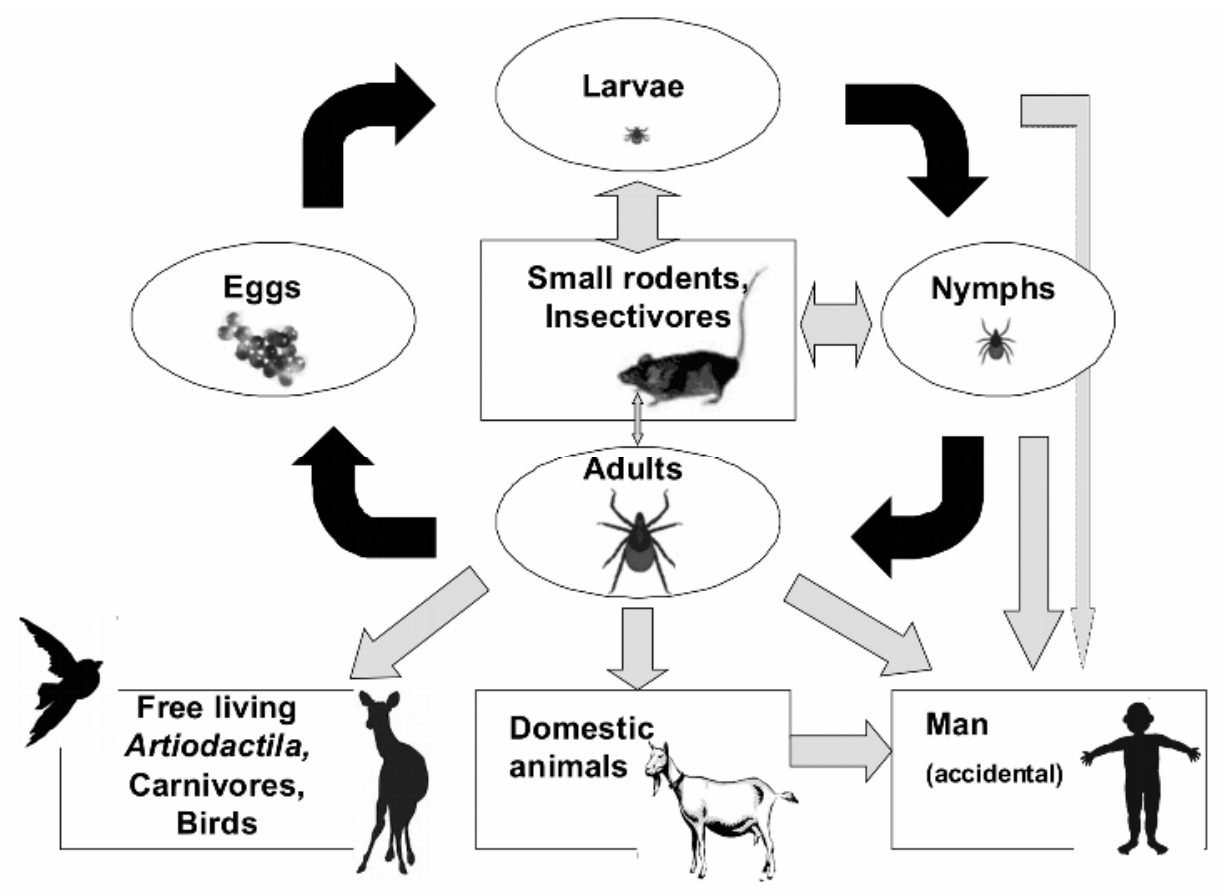

Fig. 1. Life cycle of ixodid tick and transmission cycle of TBE virus. Black lines show the cycle of ticks with different developmental stages. At each stage, a blood meal is needed to develop into the next stage. Therefore, each tick stage feeds on suitable hosts. Further, adult female ticks need a blood meal for egg production. Grey lines show the possible transmission of TBE virus. Thickness of grey arrows shows the most probable routes

Horizontal TBE virus transmission between ticks and their vertebrate reservoir hosts is necessary for virus endemism (Fig. 1) (Nuttall and Labuda, 2003). The duration of viremia in hosts is crucial for TBE virus transmission to ticks, because the virus is mostly ingested by ticks just while engorging on a viremic host. Generally, the hosts are divided into three groups: reservoir, indicator, and accidental hosts. Natural reservoir hosts of TBE virus, i.e. animals that are sensitive to the virus, exhibiting viremia for long period of time without becoming clinically ill and thus important for the transmission of the virus to ticks, include rodents (Clethrionomys, Apodemus, Mus, Microtus, Micromys, Pitymys, Arvicola, Glis, Sciurus and Citellus) (Kožuch et al., 1967), insectivores (Sorex, Talpa, Erinaceus) (Kožuch et al., 1967) and carnivores (Vulpes, Mustela) (Süss, 2003; Karabatsos, 1985). Insectivores and rodents harbor the virus also during the winter. The long-lasting viremia can be restored after the awakening of the animals after the winter sleep (posthibernation viremia). Indicator hosts have only brief viremia with low virus production and are not able to transmit the virus to vectors.

Humans are accidental hosts of TBE virus, i.e. they can develop a disease with viremia, but they do not participate in virus circulation in nature and are, therefore, a dead end of the natural TBE virus cycle. 
People can be infected (i) by a bite of an infected tick, (ii) by drinking infected unboiled milk, or (iii) by inhaling infected aerosol or by needle-stick injury. In general, most frequently TBE virus infection of humans occurs following the bite of an infected tick, which is unnoticed in about a third of cases (Kaiser, 1999). The tick usually attaches itself to man while walking in dense vegetation in forests. The virus is transmitted by saliva during first minutes of feeding. On humans, ticks prefer to attach themselves to the hair-covered portion of the head, to the arm and knee bends, hand, feet and ears as well as the gluteal and genital regions. In children, $75 \%$ of ticks are situated on the head as children are closer to vegetation than adults (Süss, 2003). The incidence of human TBE cases correlates with the activity of the ticks. The seasonal activity of I. ricinus has two peaks: April-May and September-October. Comparison of the tick population curves and the morbidity rate in humans shows that there is approximately 14 days' difference between the peaks of the two curves. The gap between the peak of tick activity and the highest morbidity rate in humans corresponds to the incubation period of the disease that is between 4 and 14 days. The activity of $I$. persulcatus has only one peak and lasts from the end of April to the beginning of June. During July only some sporadic cases can be seen. When the summer is very hot, sporadic cases can be observed even in September, but not later (Grešíková and Kaluzová, 1997). The duration of epidemic season in the Southern Far East is 6 to 7 months, since imago molt from nymphs become active at once (Leonova et al., 1996).

Another natural route of human TBE virus infection is associated with the consumption of nonpasteurized milk from viremic livestock (goats, sheep and cows). The virus can pass from the blood of the livestock into the mammary gland. Experiments and epidemiological studies have revealed that antibodies to TBE virus are readily eliminated, and one and the same goat may be repeatedly infected and may excrete TBE virus with its milk (Korenberg, 1976). If a human drinks unboiled milk from infected animals, it can lead to the development of a form of biphasic meningoencephalitis, called 'biphasic milk fever'. The virus remains stable for a relative long period also in various milk products such as yoghurt, cheese and butter (Grešíková, 1959). Persistent infectivity in gastric juice is observed after ingestion of such products for up to $2 \mathrm{~h}$ (Charrel et al., 2004). With the aim to decrease the risk of TBE infection in humans by alimentary route, a candidate life attenuated TBE virus vaccine for goats was developed (Mayer, 1966). However, recent molecular analysis of the vaccine strain revealed that this vaccination strain is not an attenuated variant of TBE virus, but a strain of virus Langat, possibly a result of laboratory contamination of cell cultures (Růžek et al., 2006).

Single cases of laboratory TBE virus infections from needle-stick injuries or associated with aerosol infection of laboratory personnel were also described (Gallia et al., 1949; Molnár and Fornosi, 1952; Hoffmann, 1973; Bodemann et al., 1977; Avšič-Županc et al., 1995).

\section{Geographical distribution}

TBE occurs in many parts of Central Europe and Scandinavia, particularly, in Austria, Czech Republic, Estonia, Finland, Germany, Hungary, Latvia, Lithuania, Poland, Russia, Slovak Republic, Slovenia, Sweden, Switzerland, and also Northern Asia (Fig. 2) (Donoso Mantke et al., 2008; Süss, 2008; Lu et al., 2008). Recently, probable TBE cases were described in Turkey (Ergünay et al., 2011). Further, new TBE foci are emerging and latent ones re-emerging in a number of other European countries (Bröker and Gniel, 2003; Petri et al. 2010). In Russia, the highest TBE incidence is reported in Western Siberia and Ural (Grešíková and Kaluzová, 1997). No TBE cases have been reported e.g. in Great Britain, Ireland, Iceland, Belgium, the 
Netherlands, Luxemburg, Spain and Portugal. Whereas Bulgaria, Croatia, Denmark, France, Greece, Italy, Norway, Romania, Serbia, China and Japan are countries with only sporadic TBE occurrence. Because of the increased mobility of people travelling to the risk areas, TBE has become an international public health problem with relation to travel medicine. The risk of an infection is especially high for people living in endemic areas or visiting them for leisure activities in nature (Bröker and Gniel, 2003).

Although TBE virus is a growing concern in Europe, surveillance and notification schemes are not uniform within the European countries. There is a lack of Europe-wide standard case definition and the quality of national surveillance programs differs considerably. Therefore, surveillance data from different countries are difficult to compare (Donoso Mantke et al., 2008).

Generally, the distribution of TBE virus correlates with ixodid tick vectors. I. ricinus occurs in most parts of Europe, and the distribution extends to the southeast (Turkey, Northern Iran, and Caucasus). I. persulcatus is seen in the wide area extending from Eastern Europe to China and Japan. Parallel occurrence of both tick species was reported in North-Eastern Europe and the east of Estonia and Latvia as well as in several European regions of Russia (Bormane et al., 2004; Golovljova et al., 2004).

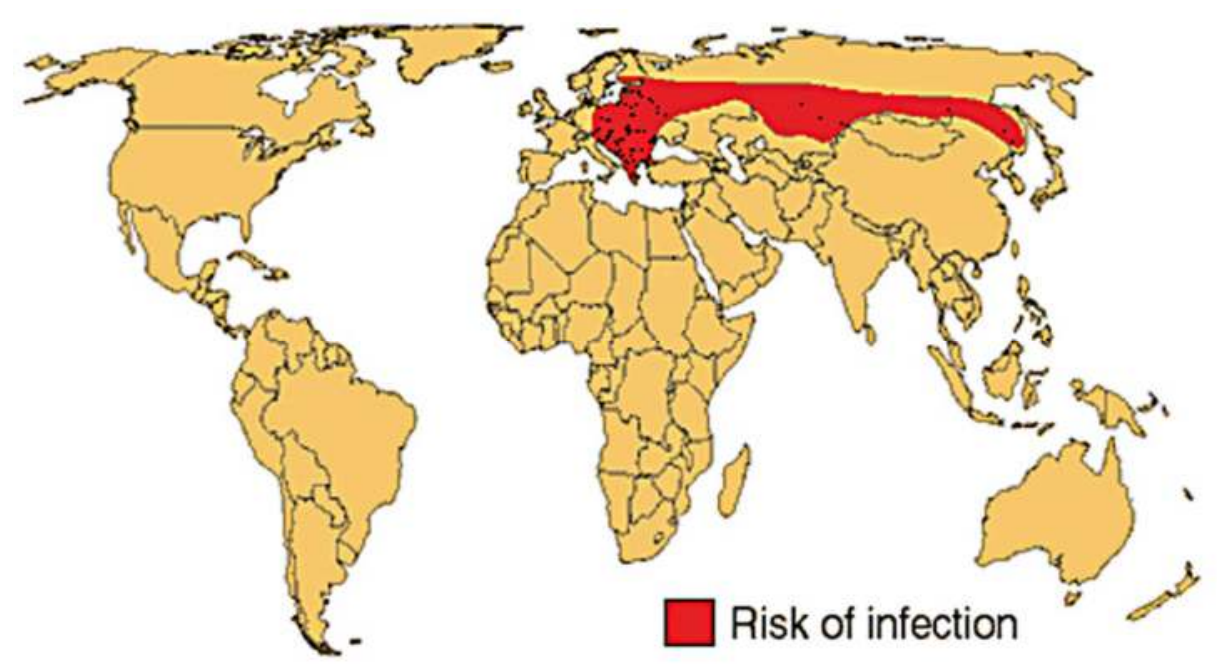

Fig. 2. Geographical distribution of TBE.

(http://www.traveldoctor.info/files/disease/10__mageFile_KrxuNAAeGEcvwVLPnxks U.gif; date of access April 11, 2011)

The increase of TBE virus incidence in most European countries during the last decades is due to a complex interrelation of several factors that include ecological (effect of climate change on the vectors), agricultural, social (changes in human leisure activities), as well as technological factors (advanced diagnostics and increased medical awareness) (Donoso Mantke et al., 2008). It has been reported that there is an increase (i) in the number of cases in areas well known for TBE in humans; (ii) a reemergence of TBE in areas where it had previously occurred but had not or only sporadically been observed since the 1970s, or (iii) the emergence of TBE in areas where it had not been known to occur previously. Shift of the 
upper limit of the geographical habitats of ticks to higher altitudes was observed in Central Europe and Sweden (Daniel et al., 2003). Previously, the limit of ticks' occurrence was at 700-750 m above sea level and ticks were not able to finish their developmental cycle at higher altitudes. However, recent studies have shown that ticks (including TBE virus infected ones) shifted to the altitudes up to 1,000 $\mathrm{m}$ above sea level. This shift is in a clear correlation with an increased average temperature since the numbers of game animals, socio-economical factors or land-usage did not change in these areas (Danielová et al., 2008). Since these mountain zones are often used for recreation and outdoor activities, the risk of TBE virus infections in these areas increased considerably (Daniel et al., 2003).

\section{Clinical picture}

Serological surveys suggest that $70-95 \%$ of human TBE virus infections are either subclinical or asymptomatic (Shapoval, 1976, 1977; Pogodina et al., 1979).

While courses and symptoms are quite similar in the early stage of disease, TBE caused by viruses of the different subtypes may vary not only in the frequency of development of certain disease forms (febrile, meningeal, meningoencephalitic, polyencephalitic, poliomyelitic, polioradiculoneuritic, and chronic forms), but also in the severity of each form.

Siberian and Far Eastern TBE virus subtypes can be the cause of chronic disease (Pogodina et al., 2004; Voronkova and Zakharycheva, 2007). For the Far Eastern TBE virus subtype, the frequency of focal encephalitic symptoms is $31-64 \%$, meningeal forms amount to nearly $26 \%$, febrile forms $14-16 \%$ and biphasic forms 3-8\%. Complete recovery occurs in $25 \%$ of all cases (Votiakov et al., 2002). The current increase in the proportion of patients with a febrile form is likely to be associated with the improved diagnostics. Case fatality rate is up to $35 \%$ (Dumpis et al., 1999). Chronic disease develops in less than $0.5 \%$ of cases.

The Siberian subtype is associated with focal encephalitic forms in $5 \%$ incidents, meningeal forms nearly $47 \%$, febrile forms $40 \%$ and biphasic forms about $21 \%$. Complete recovery occurs in $80 \%$ of all cases. Case fatality rate is nearly $2 \%$ (Votiakov et al., 2002). Nevertheless, infections with the Siberian subtype have a tendency for patients to develop chronic or extremely prolonged infections accompanied by diverse neurological and/or neuropsychiatric symptoms (Poponnikova, 2006).

However, due to differences in seroprevalence rates in Europe and in Russia, the higher morbidity of Eastern TBE forms could, at least partly, be the result of selective notification of mainly severe cases (Süss, 2003).

In contrast to the forms mentioned above, infections caused by European strains typically take a biphasic course in 72-87\% of patients (Kaiser, 1999; Günther et al., 1997; Holzmann, 2003): After a short incubation period (usually 7-14 days, with extremes of 4-28 days), the first (viremic) phase presents as an uncharacteristic influenza-like illness lasting 2-4 days (range 1-8 days) with fever, malaise, headache, myalgia, gastrointestinal symptoms, leukocytopenia, thrombocytopenia and elevated liver enzymes as frequent symptoms. This is often followed by a symptom-free interval of about one week (range 1-33 days) before the second phase. Seroconversion without prominent morbidity is common.

The second phase of TBE occurs in 20-30\% of infected patients (Gustaffson et al., 1992) and is marked by four clinical features of different severity (meningitis, meningoencephalitis, meningoencephalomyelitis or meningoencephaloradiculitis) and the appearance of specific antibodies in the serum and cerebrospinal fluid (CSF). This is usually the time when patients 
with high fever and severe headache seek medical advice. Neurological symptoms at this stage principally do not differ from other forms of acute viral meningoencephalitis (Lindquist and Vapalathi, 2008).

The fatality rate in adult patients is less than $2 \%$. However, severe courses of TBE infection with higher mortality and long-lasting sequelae often affecting the patient's quality of life have been correlated with increased age (Lindquist and Vapalathi, 2008; Mickiene et al., 2002). Further factors associated with severe forms are severity of illness in the viremic phase and low neutralizing antibody titers at onset of disease (Kaiser and Holzmann, 2000).

\section{Outbreaks history}

Although the first hints of the existence of TBE date back to Scandinavian church records from the $18^{\text {th }}$ century (Aland islands, Finland), the first medical description of the disease was given by the Austrian physician H. Schneider in 1931 (Schneider, 1931).

In 1937-39, the Russian Ministry of Health organized three successive expeditions to the Far East with the purpose to elucidate the origin of severe infections of the central nervous system (CNS), called 'taiga encephalitis' or 'biphasic meningoencephalitis', a disease that had been observed there since 1914, but more frequently occurred since 1933. Initially, the disease was misdiagnosed as a toxic form of influenza. The expeditions revealed viral origin of the disease and the tick I. persulcatus as the main vector of the virus (Zilber, 1939). The newly described disease was called 'Russian spring-summer encephalitis' (or Far East or taiga encephalitis). The virus became known as Russian spring-summer encephalitis virus and lately tick-borne encephalitis virus. After TBE virus strains were isolated, the clinical picture and human pathology aspects were described, and in 1940 the first vaccine was tested.

In the Ural, cases of Kozhevnikov's epilepsy (epilepsia corticalis sive partialis continua; for details see Vein and van Emde Boas, 2011), a supposed complication of TBE that develops after acute meningoencephalitis, were described by V.P. Pervushin in 1901 and by M.G. Polykovsky in 1917- 1920 (Votiakov et al., 2002). There, TBE virus was isolated for the first time from the brain of a deceased patient in 1939 by M.P. Chumakov and N.A. Zeitlenok (1940). The history of the discovery of TBE virus in the European part of Russia started with the investigation of a TBE outbreak in the Volkhov Front's armies in 1942-1943. In the same period, the role of I. ricinus for virus transmission was demonstrated (Petrishcheva and Levkovich, 1945), and TBE virus of the Siberian subtype was isolated from this tick (Pogodina et al., 2004). In 1946, an expedition headed by L. Zilber isolated TBE virus from $I$. ricinus ticks and from patients in Belarus. This virus was proved to be in close relationship with the then known Louping ill virus rather than with the Far Eastern TBE virus strains. Lately, the virus was named the 'Western tick-borne encephalitis virus'.

In Central Europe, TBE virus was first isolated from human patients in Czechoslovakia after the Second World War in 1948 (Gallia et al., 1949; Krejčí, 1949a) when the incidence of clinical manifestations caused by the virus was so high that it was noticed by infectiologists in affected regions (Krejčí, 1949b). Simultaneously, the virus was also isolated from I. ricinus suggesting the role of the tick as a vector of the disease (Rampas and Gallia, 1949).

Retrospective analysis, however, revealed the presence of a clinically similar disease not only in Czechoslovakia, but also in a number of other European countries for several decades before the first isolation, because many clinical neurologists and physicians have 
observed and described the disease without knowing the etiology (reviewed by Izbický, 1954). In Czechoslovakia, this disease was previously known as 'Encephalitis epidemica'. Since 1945, there was nearly a tenfold increase in the incidence of this disease (Izbický, 1954).

Shortly, after the description of TBE in Czechoslovakia, the virus was isolated in Hungary (Fornosi and Molnár, 1952), Poland (Szajna, 1954), Bulgaria (Vaptsarov et al., 1954), Yugoslavia (Bedjanič et al., 1955), Austria (Pattyn and Wyler, 1955), Romania (Draganescu, 1959), Germany (Sinnecker, 1960), but also in Finland (Oker-Blom, 1956) and Sweden (Kaäriainen et al., 1961). Simultaneously, the virus was also revealed in Northern China and Japan (Ando et al., 1952). Recently, a successful detection of TBE virus in South Korea was reported (Kim et al., 2009; Ko et al., 2010).

The clinical course of the disease, its pathology and epidemiology, as well as the properties of the virus, its ecology, and ecology of the vectors have been studied in detail. Most of the studies were carried out in Russia, Czechoslovakia and Austria (Kunz and Heinz, 2003).

The incidence of TBE varies from year to year in different geographic regions. Across Eurasia, more than 13,000 human cases are reported annually. Over the last two decades, the most dramatic changes of all were the sudden increases (2- to 30-fold) in 1992-3 in Latvia, Lithuania, Poland and Belarus, and with marked but lesser increases in Estonia, Germany, Slovakia, and the Czech Republic. TBE cases have increased steadily since the mid-1970s in Russia, and since the mid-1980s in Switzerland, Sweden, and Finland. In Austria, the only country with extensive systematic vaccination coverage, TBE incidence has decreased progressively since the early 1980s (Randolph, 2002).

Russia is the country with the largest geographical range of TBE virus and the highest TBE incidence. In the early period of descriptive TBE studies in the 1930s-1940s, 200 cases were reported annually in average (with some divergences in 1941 and 1942). The analysis of data collected since 1948 demonstrates a registered shift in 1948 followed by a peak in $1956(5,163$ cases), and by a relative plateau thereafter (3,500 cases per year in average), with the next peak in 1964 (5,204 cases). From 1964 to 1974, the incidence dropped to 1,119 cases per year. The year 1975 brought a new shift that lasted till 1999 with peaks in 1993 (7,250 cases), 1996 (10,298 cases), and 1999 (9,955 cases). In some regions, the incidence rate reached 70 per 100,000 inhabitants. A negative trend in the incidence has been observed since 2000, with 2,796 cases reported in 2008. Since 2000, the average incidence showed a two-time decrease. It should be noted that at the same time the registered trends are of opposite direction. In the extreme north-west region of Russian TBE habitats, from 1997 to 2007 a continuous positive trend was observed. In Karelia and Vologda regions, the incidence increased twice, and in the neighboring Arkhangelsk region increased five times. But since most of the cases in Russia are reported for Ural, Siberia and some Volga regions, the data for the north-west region has not material impact on the incidence rate in the country as a whole. The data on TBE incidences for Russia are based on the reports of the Federal Center of Hygiene and Epidemiology in Moscow.

In Europe, the Czech Republic ranks among the countries with the highest incidence rate of TBE. In this country, the incidence of the illness noticeably varied during the monitored period, i.e. since 1950s. The high occurrence of the infection in 1960s gradually decreased and in 1970s and 1980s reached values of 139-400 cases annually. Sporadically, there were more than 400 cases per year in 1970, 1973, and 1979. A steep increase took place in 1990s (according to data from EPIDAT, National Institute of Public Health in Prague www.szu.cz), when the annual incidence was more than two-fold higher in comparison with the preceding period, 400-600 cases per year with a maximum of 745 cases in 1995 and 
706 in 2000 (Daniel et al., 2004). In the year 2006, the incidence (1,026 cases) of TBE in the Czech Republic was almost twice as high than in the preceding years, the highest ever recorded, indicating significantly increased epidemic activity of this important human pathogen (Daniel et al., 2008). A similar increase in number of cases was observed also in other regions of Europe (www.isw-tbe.info). This phenomenon is not definitely explained. One hypothesis dealing with the increased incidence of the last years is based on impact of climatic changes on the biology of the vector I. ricinus (Gray et al., 2009). Gradual raise of the temperature in the last decades caused prolongation of the period of the tick development within a year and, subsequently, acceleration of its development and increase of the density of its population (Daniel et al., 2004). This allowed the intensification of the circulation of TBE virus, more frequent contact of man with infected ticks, and caused dissemination of the ticks and TBE to regions with no or rare previous records of their incidence (Daniel et al., 2003, 2006).

A particularly unusual outbreak was caused by infected goat milk in the Rožňava district of Slovakia in 1951-52, when at least 660 people became infected (Blaškovič, 1954; Růžek et al., 2010). Other milk-borne TBE virus outbreaks occurred in Petersburg and Moscow regions (Drozdov, 1959) in Russia and in the Styrian region of Austria (Grešíková and Kaluzová, 1994). More recently, a relatively small outbreak of TBE by alimentary route was reported in 1999 in the Czech Republic. In this case, 22 people were infected by consumption of sheep cheese. Some of the cases were severe (Daneš, 2000). In 2007, outbreak of alimentary TBE after consumption of unpasteurized raw goat milk involving 25 patients of 154 exposed persons occurred in Hungary in August 2007 (Balogh et al., 2010). Lastly, an outbreak of TBE due to consumption of goat cheese from an alpine pasture of high altitude $(1564 \mathrm{~m}$ above sea level) was reported in 2008 from an area in Vorarlberg, Austria, in which 6 persons were infected. Four of them were hospitalized with typical TBE symptoms, 2 were clinically asymptomatic (Holzmann et al., 2009).

\section{Virology}

TBE virus is the medically most important member of the tick-borne group of the genus Flavivirus, family Flaviviridae (Thiel et al., 2005). Besides TBE virus, three other tick-borne flaviviruses, i.e. Louping ill virus, Langat virus and Powassan virus, also cause encephalitis in humans and/or animals, but these infections are infrequent and the viruses do not produce significant outbreaks (Gritsun et al., 2003b).

TBE virus is subdivided into three subtypes: European (previously Central European encephalitis), Far Eastern (previously Russian spring and summer encephalitis) and Siberian (previously Western Siberian encephalitis) (Ecker et al., 1999).

Based on the antigenic similarity, the European TBE virus subtype is closely related rather to Louping ill virus than to the Far Eastern and Siberian subtypes (Hubálek et al., 1995). Moreover, on the basis of the comparison of genetic similarity of complete genomes, inclusion of Louping ill virus, Turkish sheep tick-borne encephalitis virus, and Spanish sheep encephalitis virus as different genotypes of TBE virus was proposed (Grard et al., 2007), but this classification has not been generally accepted so far, mostly because of important biological differences between these viruses.

Although TBE virus strains isolated from field collected ticks exhibit high heterogeneity with respect to their biological properties (Růžek et al., 2008), sequence analyses of various virus isolates have shown that the TBE virus is fairly homogeneous in endemic areas of Europe and is not subject to significant antigenic variations. On the other hand, the diversity 
of TBE virus from Siberian and Far Eastern subtypes is much higher. Currently, at least two groups in the Siberian genotype were identified (European and Asian groups, separated by Ural mountains) (Pogodina et al., 2007). Nevertheless, the antigenic similarity is still high enough to be sufficient for the cross-protection in the event of infection by TBE virus of the different subtypes.

The virions of TBE virus are spherical particles, approximately 50-60 nm in diameter (Slávik et al., 1967) with a nucleocapsid composed of a (+)ssRNA genome enclosed in a capsid (C) protein and surrounded by a host cell-derived lipid bilayer. The genome is approximately $11 \mathrm{~kb}$ in length and contains one large open reading frame which is flanked by $5^{\prime}$ and $3^{\prime}$ untranslated regions, with $5^{\prime}$-cap but no $3^{\prime}$-poly(A) tail. The untranslated regions form conserved secondary stem-loop structures that probably serve as cis-acting elements for genome amplification, translation and packaging (Gritsun et al., 2003b). Translation yields a 3414 amino acids long polyprotein that is co- and post-translationally cleaved by cellular and viral proteases into three structural proteins (C, prM, E) and seven non-structural proteins (NS1, NS2A, NS2B, NS3, NS4A, NS4B and NS5). The lipid envelope carries two surface proteins, the large envelope protein (E) and a small membrane protein $(\mathrm{M}) . \mathrm{M}$ protein is derived from its larger precursor, prM.

$\mathrm{C}$ protein binds viral DNA to form the virion nucleocapsid. The immature $\mathrm{C}$ protein contains a CTHD (C-terminal hydrophobic domain), i.e. a 20 amino acid length polypeptide, which is split off by serine protease to form a short CTHD polypeptide during polyprotein processing (Yamshchikov and Compans, 1993). The proteolysis site modification in this region is likely to predetermine the maturity rate of virions in the infected cells (Loktev et al., 2007).

The E protein is the major antigenic and virulence determinant of TBE virus and acts both as the ligand to the cell receptor and as the fusion protein (Lindenbach and Rice, 2003).

The viral non-structural proteins have several functions, i.e. the NS1 protein soluble homodimer is known as a complement-binding antigen; NS2A, NS4A and NS4B proteins are involved in the function as a replicative complex (Loktev et al., 2007); the complex of NS2B-NS3 proteins serves as viral serine protease; and NS5 is a RNA-dependent RNA polymerase (Lindenbach and Rice, 2003).

The infection of the host cell begins with the binding of the virus to a cell receptor, which has not been sufficiently identified till now (Kopecký et al., 1999). Apparently, just the ability to use multiple receptors can be responsible for the very wide host range of flaviviruses, which replicate in arthropods and in a broad range of vertebrates. After binding to the receptor, the virus is internalized by endocytosis. Acidification of the interior of the endosomal vesicle changes the conformation of the $\mathrm{E}$ protein and rearranges its dimers to trimeric forms. These changes result in fusion of the viral envelope and the membrane of the endosomal vesicle (Holzmann et al., 1995) and the release of the viral nucleocapsid into the cytoplasm. After uncoating, translation of the positive-stranded genome occurs, in parallel to synthesis of minus-strand RNA that serves as a template for RNA replication. Processing of the polyprotein yields the individual viral proteins (Mandl, 2005).

In vertebrate cells, virus assembly takes place in endoplasmatic reticulum and leads to formation of immature virions that contain the proteins C, prM and E. These immature particles are transported through the cellular secretory pathway and, shortly before release, prM is cleaved by furin or a similar enzyme in the acidic compartment of the trans-Golgi network to yield mature and fully infectious virions (Mandl, 2005).

However, the TBE virus maturation process in tick cells is completely different than in the cells from vertebrate hosts. In cell lines derived from the tick Rhipicephalus appendiculatus 
infected with TBE virus, nucleocapsids occur in cytoplasm and the envelope is acquired by budding on cytoplasmic membrane or into cell vacuoles (Šenigl et al., 2006). The studies focused on the adaptation of TBE virus to Hyalomma marginatum ticks and mammals described the presence of respective adaptive mutations within the second domain of $\mathrm{E}$ protein (Romanova et al., 2007).

Most of the studies on TBE pathogenesis have been done on laboratory mice that are susceptible to TBE virus and develop lethal infection of CNS (Simon et al., 1966), analogous to severe cases of TBE in humans (Mandl, 2005).

After the tick bite, the virus replicates in subcutaneous tissues (Fig. 3). Dendritic cells in the skin are likely to serve as a vehicle for the transport of the virus to draining lymph nodes (Labuda et al., 1996). The lymph nodes play an important part in the pathogenesis of TBE. However, virus replication is not accompanied by any virus-specific histological changes including any destruction of cells in the nodes (Málková and Filip, 1968). On the model of Syrian hamsters inoculated intracerebrally with TBE virus strains differing in virulence, specific involvement of the organs of the immune system (spleen, lymph nodes, and thymus) was established and morphological features of the process described. The most severe destructive changes of these organs (mass disintegration of lymphocytes, inhibition of their migration, almost complete inhibition of regeneration processes up to the complete elimination of germinal centers) were found in the hamsters inoculated with highly virulent strains (Karmysheva and Pogodina, 1990). TBE virus can be isolated from blood leucocytes during the first days after the tick bite indicating virus replication in immunocompetent blood cells (Leonova and Maistrovskaya, 1996).

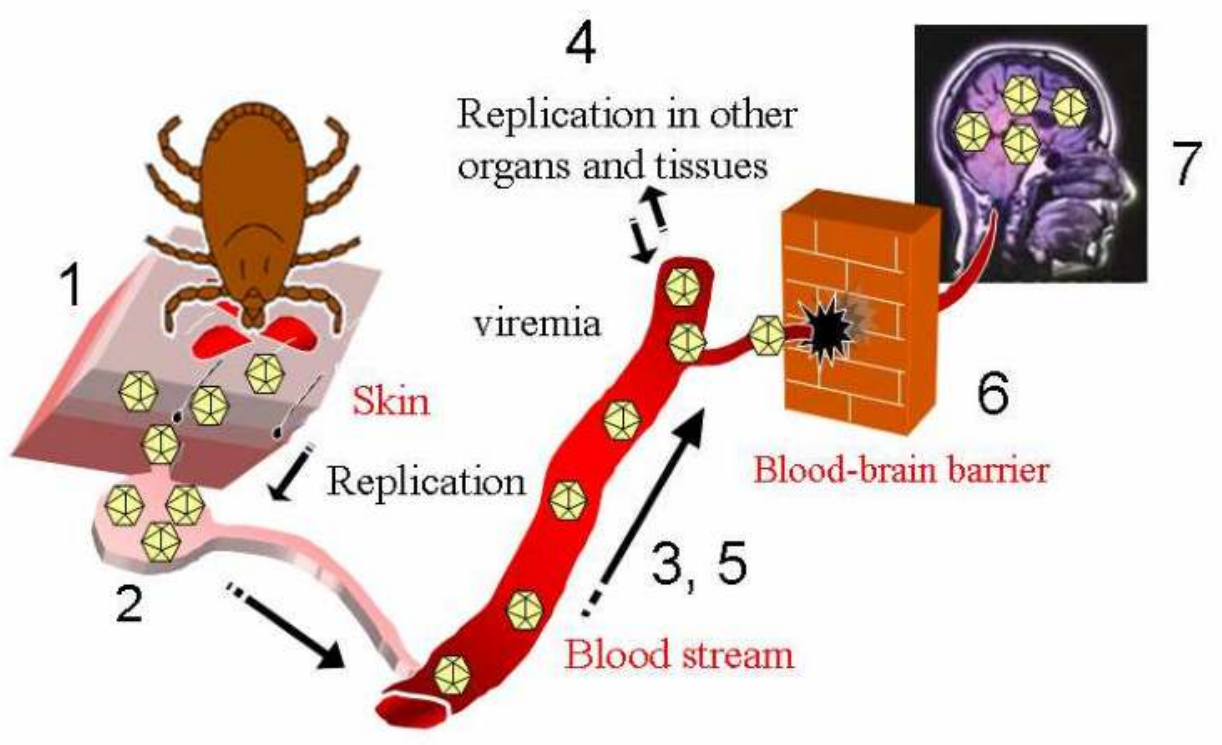

Fig. 3. Schematic drawing of the steps during TBE virus infection. (1) TBE virus transmission from an infected tick, (2) TBE virus replication in regional lymph node, (3) primary viremia, (4) replication of the virus in other organs and tissues, (5) secondary viremia, (6) TBE virus crossing of the blood-brain barrier, and (7) virus infection of the brain 
Massive viral multiplication in the nodes leads to the spreading of virus into the blood stream and induction of viremia (Málková et al., 1969). Temporary leukopenia in the white blood picture is observed. A significant decrease is recorded in all cellular elements. In regional lymph nodes, a significant decrease in lymphocytes appears (Málková et al., 1961). Many extraneural tissues are infected during the viremic phase and, subsequently during the secondary viremia, the virus invades the CNS by still unknown mechanism. Mice dying due TBE exhibite severe systemic stress response, and increased levels of TNF-alpha compared with recovering mice (Hayasaka et al., 2009). Characteristic, but not diseasespecific, are neuropathologic changes in CNS that include meningitis and polioencephalomyelitis accentuated in spinal cord, brainstem and cerebellum associated with inflammatory cell infiltration of infected animals (Gelpi et al., 2005). In mice, as well as in human post-mortem cases, prominent inflammatory infiltrates and cytotoxic T-cells were observed in close contact with morphologically intact neurons suggesting a key role for cytotoxic T-cells in the development of encephalitis (Gelpi et al., 2006; Růžek et al., 2009). Recent studies confirmed, that the host $\mathrm{CD}^{+} \mathrm{T}$-lymphocytes infiltrating brain parenchyma mediate immunopathology in TBE (Růžek et al., 2009). Thus, the host immune system contributes significantly to the development and higher severity of the disease.

TBE virus infection, in addition to causing fatal encephalitis in mice, induces considerable breakdown of the blood-brain barrier (BBB). The permeability of the BBB increases at later stages of TBE infection when high virus load is present in the brain (i.e., BBB breakdown was not necessary for TBE virus entry into the brain), and at the onset of the first severe clinical symptoms of the disease. The increased BBB permeability is in association with dramatic upregulation of proinflammatory cytokine/chemokine mRNA expression in the brain. Breakdown of the BBB can be also observed in mice deficient in CD8 ${ }^{+} \mathrm{T}$-cells, indicating, that these cells are not necessary for the increase in BBB permeability that occurs during TBE (Růžek et al., 2011).

\section{Laboratory diagnosis}

Since TBE shows clinical and laboratory findings similar to other CNS diseases which may require special treatment, microbiological laboratories have to perform specific diagnostics mainly for differential diagnosis (Donoso Mantke et al., 2007a).

This can be done (i) as direct detection of the virus or viral RNA in the first (viremic) phase of infection, by virus isolation in mammalian cell culture or RT-PCR, or (ii) as indirect detection of specific IgM and IgG antibodies with serological methods as enzyme immunoassay, immunofluorescence assay or neutralization test.

As the majority of patients come for medical attention when neurological symptoms are manifest, it is the current experts' opinion that virus isolation and RT-PCR at this time are of minor importance for the diagnosis of TBE, because at the beginning of the second phase of illness the virus itself is only rarely detectable in blood and CSF. Therefore, the diagnosis of TBE is mainly done by serological methods, usually enzyme-linked immunosorbent assay (ELISA) based on purified virions or recombinant virus-like particles, which have been developed towards higher specificity and sensitivity in the last decade (Holzmann, 2003; Sonnenberg et al., 2004; Günther and Haglund, 2005; Ludolfs et al., 2009).

However, detection by PCR methods could be valuable for an early differential diagnosis of TBE (Saksida et al., 2005; Schultze et al., 2007). This is particularly true for patients living in or coming from areas where more than one tick-transmitted disease is endemic. Detection of 
specific nucleic acid from blood and CSF depends on the sampling at the right time. The highest yield of TBE virus specific RNA is obtained during the transient viremia in the first week of the disease, much less in the second week after the appearance of antibodies and only occasionally later on (Holzmann, 2003; Puchhammer-Stöckl et al., 1995).

The benefit of molecular detection methods depends on the attention that affected people and clinicians pay to tick bites and symptoms. The earlier a correct diagnosis is obtained (e.g. TBE or other etiology), the earlier an appropriate therapy can be introduced. This could have dramatic influence upon survival and outcome of a suspected CNS disease.

RT-PCR can also be of great diagnostic help when the patient has not developed antibodies at the beginning of the second phase, has a severe case of TBE or has died after a relatively short course of infection (Gelpi et al., 2005; Schwaiger and Cassinotti, 2003).

Both serological and molecular detection methods for TBE are useful as single applications or in combination for clinical diagnosis, immunity testing, epidemiological surveillance and survey of virus prevalence in ticks and vertebrate hosts.

Although ELISA is currently the method of choice, due to its simple performance and ease of automation, and new commercial serological assays have been developed with higher sensitivity and specificity, certain restrictions have to be taken into consideration for the application of serological methods (Table 1).

\begin{tabular}{|c|c|c|}
\hline Method & Serology & RT-PCR \\
\hline Advantages & $\begin{array}{l}\text {-Allows reliable detection of } \\
\text { IgM and IgG antibodies in } \\
\text { serum and CSF up from the } \\
2^{\text {nd }} \text { week of disease } \\
\text { - High throughput of clinical } \\
\text { specimens is possible } \\
\text { - Commercial kits are } \\
\text { available }\end{array}$ & $\begin{array}{l}\text { - Allows early diagnosis } \\
\text { by detection of TBE virus } \\
\text { specific RNA in the first } \\
\text { phase of infection, if } \\
\text { patient is hospitalized at } \\
\text { this time point } \\
\text { - Provides opportunity to } \\
\text { discriminate between } \\
\text { TBE virus subtypes } \\
\text { - Provides opportunity to } \\
\text { quantify viral load }\end{array}$ \\
\hline Disadvantages & $\begin{array}{l}\text { - Cross-reactions with } \\
\text { antibodies elicited by other } \\
\text { flaviviruses } \\
\text { - Neutralization test has a } \\
\text { high specificity, but requires } \\
\text { higher containment } \\
\text { laboratory }\end{array}$ & $\begin{array}{l}\text { - Requires trained } \\
\text { laboratory personnel for } \\
\text { proper handling }\end{array}$ \\
\hline
\end{tabular}

Table 1. Advantages and disadvantages of serology and RT-PCR for the diagnosis of TBE (modified from Donoso Mantke et al., 2007a)

An early diagnosis by detecting only IgM is questionable, since IgM antibodies can persist for up to 10 months in vaccinees or individuals who acquired the infection naturally. Therefore, confirmation by detection of specific IgG is recommended, but may turn out negative in the first phase of infection. The necessary monitoring of an increase of IgG titers 
1-2 weeks later is rarely done. Moreover, a major problem when using ELISA and immunofluorescence assays lays in the high cross-reactivity of the flaviviral antigenic structure. Possible diagnostic difficulties may arise due to cross-reactions of antibodies elicited by other flavivirus infections or vaccinations. This could happen in areas where other flaviviruses co-circulate (e.g. West Nile virus in the southern parts of the TBE endemic area), in patients recently returned from areas endemic for other flaviviruses (e.g. dengue virus endemic areas) or in individuals being vaccinated against TBE virus, Japanese encephalitis or yellow fever virus (Holzmann, 2003; Niedrig et al., 2001).

Thus, verification of positive results by neutralization test is advised which, due to the use of infectious virus particles, requires the handling in higher containment laboratories which makes this test time-consuming and expensive.

As mentioned, the molecular diagnostics for TBE are restricted to the first (viremic) phase of infection. But, in combination with a higher awareness of the disease, this fact could be more an advantage than an obstacle, leading to an early diagnosis of TBE (Table 1).

Also, the RT-PCR provides the opportunity to discriminate between all subtypes of TBE. This could be an important aspect while facing co-circulation of the different subtypes in some European regions (Růžek et al., 2007; Achazi et al., 2011). Unfortunately, a negative PCR result in serum or CSF of a patient is not predictive for the absence of a TBE infection. This may be caused either by the short viremia of the infection, by sampling at inappropriate times and/or by improper handling of diagnostic specimens. The lack of commercial assays of standardized quality provides another reason why RT-PCR has not been established so far in microbiological laboratories for TBE diagnosis (Donoso Mantke et al., 2007a). The presence of many in-house assays especially for the molecular detection of TBE requires quality control studies in order to avoid false positive and/or negative results and to achieve the same diagnostic quality among the different assays (Donoso Mantke et al., 2007b).

\section{Prevention and treatment}

Besides general preventive measures, like wearing appropriate clothing or checking the skin for attached ticks, TBE can be successfully prevented by active immunization (Kunz, 2003; Heinz et al., 2007).

In Russia, several vaccines are produced by using Far Eastern TBE subtype viruses: e.g. the vaccine of the Institute of Poliomyelitis and Viral Encephalitis (IPVE), in Moscow with strain Sofjin, and EnceVir by Virion, in Tomsk with strain 205.

In Europe two vaccines are available which are based on European TBE virus strains: FSMEIMMUN by Baxter Bioscience, Orth an der Donau, Austria with strain Neudoerfl, and Encepur by Novartis Vaccines and Diagnostics, Marburg, Germany with strain K23.

The large envelope protein $\mathrm{E}$ induces the production of neutralizing antibodies important for the protective immunity. Due to the highly conserved structure of this antigen broad cross-protection by the vaccines could be shown against TBE viruses of all three subtypes (Ecker et al., 1999; Leonova and Maistrovskaya, 1996; Klockmann et al., 1991; Holzmann et al., 1992; Hayasaka et al., 2001).

Since their introduction both European vaccines have undergone several modifications and are manufactured by the same steps during the production process (Rendi-Wagner, 2008). Viral antigens are propagated in chick embryo cells, filtered and inactivated by formaldehyde, and purified by ultracentrifugation. During the formulation the antigens are adsorbed to aluminium hydroxide and stabilized with human albumin (FSME-IMMUN) or 
sucrose (Encepur). Thiomersal was removed from both vaccine formulations in the 1990s to fulfill high safety and tolerability standards (Barrett et al., 2003).

The conventional immunization schedules for primary immunization are similar for both vaccines, with three intramuscular doses given on 0,21 days-3 months and 9-12 months. Thus, both vaccines induce antibody concentrations that are believed to be protective in over $90 \%$ of children and adults (Lindquist and Vapalathi, 2008). Due to the high homology of the antigens and demonstrated cross-boostering in clinical studies, the two TBE vaccines seem interchangeable after a complete primary immunization (Rendi-Wagner et al., 2004; Bröker and Schöndorf, 2006). So far, the protective amount of antibodies is not clearly defined and standardized for both vaccines. Also, occasional vaccine breakthroughs have been reported (Bender et al., 2004; Kleiter et al., 2007; Andersson et al., 2010).

Besides vaccines for adults, both European vaccine manufacturers offer pediatric vaccine formulations containing half the dose of viral antigen of the adult ones to improve tolerability in children (Zent et al., 2003; Pavlova et al., 2003; Pöllabauer et al., 2010).

An age-dependent immune response after vaccination could be shown, with children having an enhanced response in comparison to adults (Girgsdies et al., 1996), whereas especially vaccinees aged over 60 years frequently have a poor antibody response (Hainz et al., 2005).

Data regarding the persistence of post-immunization antibodies led the manufacturers to change their recommendations (Rendi-Wagner, 2008). Regular boosters are recommended every 5 years for age-groups $\leq 49$ years of age (except for the first booster after 3 years). In age-groups $>49$ years of age a 3-year-booster interval is recommended due to the significantly gradual decline of post-immunization antibodies.

Rapid immunization schedules have been introduced by both vaccine producers for people who require immunity at short notice, such as travelers travelling to TBE-endemic areas or when the tick season has already started. However, since the experience with TBE vaccines is mainly based on the conventional immunization schedules, these should be always applied wherever possible.

In Russia, IPVE vaccine is applied for adults and children of three years and over, the vaccine is given in two doses over 5-7 months with the revaccination after 1 year, and then every 3 years. EnceVir vaccine is administered to adults aged 18 years and more, the vaccine is also given in two doses over 5-7 months, with the revaccination after 1 year and every 3 years thereafter. This vaccine is also available for the rapid immunization schedule: two doses over 1-2 months.

Clinical therapy is only symptomatic with strict bed rest, usually in an intensive care unit, until the fever and neurological symptoms have subsided. Maintenance of water and electrolyte balances, sufficient caloric intake, and administration of analgesics, vitamins, and antipyretics are the central pillars of clinical treatment of TBE patients.

Since there is no specific treatment for TBE available to date, and the administration of hyperimmunoglobulin for a passive post-exposure prophylaxis is highly questionable concerning the virtue and not recommended anymore due to concerns about antibodydependent enhancement of infection (Kaiser, 1999; Waldvogel et al., 1996; Jones et al., 2007), active immunization should always be recommended for people living in or travelling to TBE endemic areas.

\section{Future trends}

Since the first descriptions of TBE and its viral etiology in the 1930s/1940s the scientific development in this research area has been tremendous. Today, we have knowledge about 
the structure and molecular biology of TBE virus and the biotic and non-biotic factors underlying its natural cycle. Also, there are effective and safe purified inactivated vaccines available on the market, which made vaccination an extremely successful measure for preventing the disease.

However, there are several issues in the context of TBE which need to be deepened in the future, like:

1. Further development of rapid differential diagnosis of TBE virus in combination with other tick-borne pathogens by detecting both the nucleic acids and viral antigens.

2. Further efforts in identifying the genetic basis of TBE virulence.

3. Study of interaction of virus and immune cells for further prognosis of clinical course and outcome of TBE and, if possible, for better treatment.

4. Establishment of international databases for TBE virus: epidemic risks, individual risks, mapping and characterization of natural foci, circulating genotypes, circulation of other tick-borne pathogens in TBE foci.

5. The taxonomic position of Louping ill virus (and subtypes Turkish sheep-, Spanish sheep encephalitis virus) and Greek goat encephalitis virus is under consideration.

\section{Acknowledgements}

We acknowledge financial support by the Czech Science Foundation project No. P302/10/P438 and No. P502/11/2116, and grants Z60220518 and LC06009 from the Ministry of Education, Youth, and Sports of the Czech Republic.

\section{References}

Achazi, K., Nitsche, A., Patel, P., Radonić, A., Donoso Mantke, O., and Niedrig, M. 2011. Detection and differentiation of tick-borne encephalitis virus subtypes by a reverse transcription quantitative real-time PCR and pyrosequencing. J. Virol. Methods 171(1):34-9.

Andersson CR, Vene S, Insulander M, Lindquist L, Lundkvist A, Günther G. Vaccine failures after active immunisation against tick-borne encephalitis. Vaccine. $2010 \mathrm{Apr}$ 1;28(16):2827-31.

Ando, K., Kuratsuka, K., Arima, S., Hironaka, N., Honda, Y., and Ishii, K. 1952. Studies on the viruses isolated during epidemic of Japanese B encephalitis in 1948 in Tokyo area. Kitasato. Arch. Exp. Med. 24: 49-61.

Avsic-Zupanc, T., Poljak, M., Maticic, M., Radsel-Medvescek, A., LeDuc, J.W., Stiasny, K., Kunz, C., and Heinz, F.X. 1995. Laboratory acquired tick-borne meningoencephalitis: characterisation of virus strains. Clin. Diagn. Virol. 4: 51-9.

Balogh, Z., Ferenczi, E., Szeles, K., Stefanoff, P., Gut, W., Szomor, K.N., Takacs, M., and Berencsi, G. 2010. Tick-borne encephalitis outbreak in Hungary due to consumption of raw goat milk. J. Virol. Methods 163(2):481-5.

Barrett, P.N., Schober-Bendixen, S., and Ehrlich, H.J. 2003. History of TBE vaccines. Vaccine 21 (Suppl 1): S41-9.

Bedjanič, M., Rus, S., Kmet, J., Vesenjak-Zmijanac, J. 1955 Virus meningo-encephalitis in Slovenia. Bull. World Health Organ. 12: 503-12. 
Benda, R. 1958. [The common tick "Ixodes ricinus" as a reservoir and vector of tick-borne encephalitis. I. Survival of the virus (strain B3) during the development of ticks under laboratory condition]. J. Hyg. Epidemiol. (Prague) 2: 314-30.

Bender, A., Jäger, G., Scheuerer, W., Feddersen, B., Kaiser, R., and Pfister, H.W. 2004. Two severe cases of tickborne encephalitis despite complete active vaccination - the significance of neutralizing antibodies. J. Neurol. 251: 353-4.

Blaškovič, D. 1954 [Outbreak of tick-borne encephalitis in Rožňava natural focus]. Bratislava: Vydavatelstvo SAV. [Book in Slovak]

Bodemann, H., Pausch, J., Schmitz, H., and Hoppe-Seyler, G. 1977. [Die Zeckenenzephalitis (FSME) als Laborinfektion]. Med. Welt 28: 1779-81. [Article in German]

Bormane, A., Lucenko, I., Duks, A., Mavtchoutko, V., Ranka, R., Salmina, K., and Baumanis, V. 2004. Vectors of tick-borne diseases and epidemiological situation in Latvia in 1993-2002. Int. J. Med. Microbiol. 293(Suppl 37): 36-47.

Bröker, M., and Gniel, D. 2003. New foci of tick-borne encephalitis virus in Europe: consequences for travellers from abroad. Travel Med. Infect. Dis. 1: 181-4.

Bröker, M., and Schöndorf, I. 2006. Are tick-borne encephalitis vaccines interchangeable? Expert Rev. Vaccines 5: 461-6.

Charrel, R.N., Attoui, H., Butenko, A.M., Clegg, J.C., Deubel, V., Frolova, T.V., Gould, E.A., Gritsun, T.S., Heinz, F.X., Labuda, M., Lashkevich, V.A., Loktev, V., Lundkvist, A., Lvov, D.V., Mandl, C.W., Niedrig, M., Papa, A., Petrov, V.S., Plyusnin, A., Randolph, S., Süss, J., Zlobin, V.I., and de Lamballerie X. 2004. Tick-borne virus diseases of human interest in Europe. Clin. Microbiol. Infect. 10: 1040-55.

Chumakov, M.P., and Zeitlenok, N.A. 1940 [Tick-borne Spring-Summer encephalitis in the Ural region. In: Neuroinfections in the Ural]. Sverdlovsk; pp. 23-30. [Chapter in Russian]

Daneš, L. 2000. [Human infections with tick-borne encephalitis virus]. Medicina 3: 16. [Article in Czech]

Daniel, M., Danielová, V., Kř́žz, B., and Beneš, Č. 2006. In: Menne B, Ebi KL, Eds. Climate change and adaptation strategies for human health. Steinkopff, Darmstadt, Springer, pp. 189-205.

Daniel, M., Danielová, V., Kříž, B., and Kott, I. 2004. An attempt to elucidate the increased incidence of tick-borne encephalitis and spread to higher altitudes in the Czech Republic. Int. J. Med. Microbiol. 293(Suppl 37): 55-62.

Daniel, M., Danielová, V., Kř́žz, B., Jirsa, A., and Nožička, J. 2003. Shift of the tick Ixodes ricinus and tick-borne encephalitis to higher altitudes in Central Europe. Eur. J. Clin. Microbiol. Infect. Dis. 22: 327-8.

Daniel, M., Kř́̌ž, B., Danielová, V., and Beneš, C. 2008 Sudden increase in tick-borne encephalitis cases in the Czech Republic, 2006. Int. J. Med. Microbiol. 298(Suppl. 1): 81-7.

Danielová, V., Kliegrová, S., Daniel, M., and Beneš, Č. 2008. Influence of climate warming on tick-borne encephalitis expansion to higher altitudes over the last decade (19972006) in the Highland Region (Czech Republic). Cent. Eur. J. Public Health 16: 4-11.

Donoso Mantke, O., Aberle, S.W., Avsic-Zupanc, T., Labuda, M., and Niedrig, M. 2007b. Quality control assessment for the PCR diagnosis of tick-borne encephalitis virus infections. J. Clin. Virol. 38: 73-7. 
Donoso Mantke, O., Schädler, R., and Niedrig, M. 2008. A survey on cases of tick-borne encephalitis in European countries. Euro Surveill. 13(17). pii: 18848.

Donoso-Mantke, O., Achazi, K., and Niedrig, M. 2007a. Serological versus PCR methods for the detection of tick-borne encephalitis virus infections in humans. Future Virology 2: 565-72.

Draganescu, N. 1959. [Inframicrobial meningoencephalitis belonging to the group transmitted by arthropods. Identification of the pathogenic agent and study of the nerve lesions induced in white mice] Stud. Cercet. Inframicrobiol. 10: 363-9. [Article in Romanian]

Drozdov, S.G. 1959. [Role of domestic animals in epidemiology of diphasic milk fever]. Zh. Microbiol. Epidemiol. Immunobiol. 30: 102-8. [Article in Russian]

Dumpis, U., Crook, D., and Oksi, J. 1999. Tick-borne encephalitis. Clin. Infect. Dis. 28: 882-90.

Ecker, M., Allison, S.L., Meixner, T., and Heinz, F.X. 1999. Sequence analysis and genetic classification of tick-borne encephalitis viruses from Europe and Asia. J. Gen. Virol. 80: 179-85.

Ergünay, K., Saygan, M.B., Aydoğan, S., Litzba, N., Sener, B., Lederer, S., Niedrig, M., Hasçelik, G., and Us, D. 2011. Confirmed exposure to tick-borne encephalitis virus and probable human cases of tick-borne encephalitis in central/northern anatolia, Turkey. Zoonoses Public Health 58(3):220-7.

Fornosi, F., and Molnár, E. 1952. [Meningoencephalitis in Hungary] Orv. Hetil. 93: 993-6. [Article in Hungarian]

Gallia, F., Rampas, J., and Hollender, L. 1949. [Laboratory infection caused by tick-borne encephaltis virus]. Čas. Lék. čes. 88: 224-9. [Article in Czech]

Gelpi, E., Preusser, M., Garzuly, F., Holzmann, H., Heinz, F.X., and Budka, H. 2005. Visualization of Central European tick-borne encephalitis infection in fatal human cases. J. Neuropathol. Exp. Neurol. 64: 506-12.

Gelpi, E., Preusser, M., Laggner, U., Garzuly, F., Holzmann, H., Heinz, F.X., and Budka, H. 2006. Inflammatory response in human tick-borne encephalitis: analysis of postmortem brain tissue. J. NeuroVirol. 12: 322-7.

Girgsdies, O.E., and Rosenkranz, G. 1996. Tick-borne encephalitis: development of a paediatric vaccine. A controlled, randomized, double-blind and multicentre study. Vaccine 14: 1421-8.

Golovljova, I., Vene, S., Sjölander, K.B., Vasilenko, V., Plyusnin, A., and Lundkvist, A. 2004. Characterization of tickborne encephalitis virus from Estonia. J. Med. Virol. 74: 5808.

Grard, G., Moureau, G., Charrel, R.N., Lemasson, J.J., Gonzalez, J.P., Gallian, P., Gritsun, T.S., Holmes, E.C., Gould, E.A., and de Lamballerie, X. 2007. Genetic characterization of tick-borne flaviviruses: new insights into evolution, pathogenetic determinants and taxonomy. Virology 361: 80-92.

Gray, J.S., Dautel, H., Estrada-Peña, A., Kahl, O., and Lindgren, E. 2009. Effects of climate change on ticks and tick-borne diseases in Europe. Interdiscip. Perspect. Infect. Dis. 2009: 593232.

Grešíková, M. 1959. [Persistence of tick-borne encephalitis virus infection in milk and milk products]. Čs. Epidem. Mikrobiol. Immunol. 8: 26-32. [Article in Czech]

Grešíková, M., and Kaluzová, M. 1997. Biology of tick-borne encephalitis virus. Acta Virol. 41: 115-24. 
Grešíková, M., and Nosek, J. 1966. Isolation of tick-borne encephalitis virus from Haemaphysalis inermis ticks. Acta Virol. 10: 359-61.

Gritsun, T.S., Frolova, T.V., Zhankov, A.I., Armesto, M., Turner, S.L., Frolova, M.P., Pogodina, V.V., Lashkevich, V.A., and Gould, E.A.2003a. Characterization of a Siberian virus isolated from a patient with progressive chronic tick-borne encephalitis. J. Virol. 77: 25-36.

Gritsun, T.S., Lashkevich, V.A., and Gould, E.A. 2003b. Tick-borne encephalitis. Antiviral Res. 57: 129-46.

Günther, G., and Haglund, M. 2005. Tick-borne encephalopathies: epidemiology, diagnosis, treatment and prevention. CNS Drugs 19: 1009-32.

Günther, G., Haglund, M., Lindquist, L., Forsgren, M., and Sköldenberg, B. 1997. Tick-borne encephalitis in Sweden in relation to aseptic meningoencephalitis of other etiology: a prospective study of clinical course and outcome. J. Neurol. 244: 230-8.

Gustafson, R., Svenungsson, B., Forsgren, M., Gardulf, A., and Granstrom, M. 1992. Twoyear survey of the incidence of Lyme borreliosis and tick-borne encephalitis in a high-risk population in Sweden. Eur. J. Clin. Microbiol. Infect. Dis. 11: 894-900.

Hainz, U., Jenewein, B., Asch, E., Pfeiffer, K.P., Berger, P., and Grubeck-Loebenstein, B. 2005. Insufficient protection for healthy elderly adults by tetanus and TBE vaccines. Vaccine 23: 3232-5.

Hayasaka, D., Goto, A., Yoshii, K., Mizutani, T., Kariwa, H., and Takashima, I. 2001. Evaluation of European tick-borne encephalitis virus vaccine against recent Siberian and far-eastern subtype strains. Vaccine 19: 4774-9.

Hayasaka, D., Nagata, N., Fujii, Y., Hasegawa, H., Sata, T., Suzuki, R., Gould, E.A., Takashima, I., and Koike, S. 2009. Mortality following peripheral infection with tick-borne encephalitis virus results from a combination of central nervous system pathology, systemic inflammatory and stress responses. Virology 390(1):139-50.

Heinz, F.X., Holzmann, H., Essl, A., Kundi, M. 2007. Field effectiveness of vaccination against tick-borne encephalitis. Vaccine 25: 7559-67.

Hoffmann, H. 1973. [Die unspezifische Abwehr bei neurotropen Arbovirusinfektionen]. Zbl. Bakt. Hyg. I. Abt. [Orig. A] 223: 143-63. [Article in German]

Holzmann, H. 2003. Diagnosis of tick-borne encephalitis. Vaccine 21(Suppl 1): S36-40.

Holzmann, H., Aberle, S.W., Stiasny, K., Werner, P., Mischak, A., Zainer, B., Netzer, M., Koppi, S., Bechter, E., and0 Heinz, F.X. 2009. Tick-borne encephalitis from eating goat cheese in a mountain region of Austria. Emerg Infect. Dis. 15(10):1671-3.

Holzmann, H., Stiastny, K., York, H., Dorner, F., Kunz, C., and Heiz, F.X. 1995. Tick-borne encephalitis virus envelope protein E-specific monoclonal antiobodies for the study of low $\mathrm{pH}$-induced conformational changes and immature virions. Arch. Virol. 140: 213-21.

Holzmann, H., Vorobyova, M.S., Ladyzhenskaya, I.P., Ferenczi, E., Kundi, M., Kunz, C., and Heinz, F.X. 1992. Molecular epidemiology of tick-borne encephalitis virus: crossprotection between European and Far Eastern subtypes. Vaccine 10: 345-9.

Hubálek, Z., Pow, I., Reidl, H.W., and Hussain, M.H. 1995. Antigenic similarity of Central European encephalitis and louping-ill viruses. Acta Virol. 39: 251-6.

Izbický, A. [Current situation in the research of epidemiology of Czechoslovak tick-borne encephalitis]. Dissertation Thesis in Czech. Prague: Prof. Raška Institute of Epidemiology and Microbiology 1954. 
Jones, N., Sperl, W., Koch, J., Holzmann, H., and Radauer, W. 2007. Tick-borne encephalitis in a 17-dayold newborn resulting in severe neurologic impairment. Pediatr. Infect. Dis. J. 26: 185-6.

Kaäriainen, L.E., Hirvonen, E., and Oker-Blom, N. 1961. Geographical distribution of biphasis tick-borne encephalitis in Finland. Ann. Med. Exp. Fenn. 39: 316-28.

Kaiser, R. 1999. The clinical and epidemiological profile of tick-borne encephalitis in southern Germany 1994-98: a prospective study of 656 patients. Brain 122( $\mathrm{Pt} \mathrm{11):}$ 2067-78.

Kaiser, R., and Holzmann, H. 2000. Laboratory findings in tick-borne encephalitis correlation with clinical outcome. Infection 28: 78-84.

Karabatsos, N. (Ed.) International Catalogue of Arboviruses. Including certain other viruses of vertebrates. 3rd ed. San Antonio: American Society of Tropical Medicine and Hygiene, 1985.

Karmysheva, V.Ia., and Pogodina, V.V. 1990. [Thymus involvement in the pathogenesis of experimental tick-borne encephalitis]. Vopr. Virusol. 35: 144-6. [Article in Russian]

Kim, S.Y., Jeong, Y.E., Yun, S.M., Lee, I.Y., Han, M.G., and Ju, Y.R. 2009. Molecular evidence for tick-borne encephalitis virus in ticks in South Korea. Med. Vet. Entomol. 23: 1520.

Kleiter, I., Jilg, W., Bogdahn, U., and Steinbrecher, A. 2007. Delayed humoral immunity in a patient with severe tick-borne encephalitis after complete active vaccination. Infection 35: 26-9.

Klockmann, U., Křivanec, K., Stephenson, J.R., and Hilfenhaus, J. 1991. Protection against European isolates of tick-borne encephalitis virus after vaccination with a new tickborne encephalitis vaccine. Vaccine 9: 210-2.

Ko, S., Kang, J.G., Kim, S.Y., Kim, H.C., Klein, T.A., Chong, S.T., Sames, W.J., Yun, S.M., Ju, Y.R., and Chae, J.S. 2010. Prevalence of tick-borne encephalitis virus in ticks from southern Korea. J. Vet. Sci. 11(3):197-203.

Kopecký, J., Grubhoffer, L., Kovář, V., Jindrák, L., and Vokurková, D. 1999. A putative host cell receptor for tick-borne encephalitis virus identified by antiidiotypic antibodies and virus affinoblotting. Intervirology 42: 9-16.

Korenberg, E.I. 1976. Some contemporary aspects of natural focality and epidemiology of tick-borne encephalitis. Folia Parasitol. 23: 357-366.

Korenberg, E.I., Kuznetsova, R.I., Kovalevskiĭ, Iu.V., Vasilenko, Z.E., and Mebel', B.D. 1991. [The basic epidemiological traits of Lyme disease in the northwestern USSR]. Med. Parazitol. (Mosk) 3: 14-7. [Article in Russian]

Kožuch, O., Grešíková, M., Nosek, J., Lichard, M., and Sekeyová, M. 1967. The role of small rodents and hedgehogs in a natural focus of tick-borne encephalitis. Bull. World Health Organ. 36(Suppl 1): 61-6.

Krejčí, J. 1949a. Isolement d'un virus noveau en course d'un epidémie de meningoencephalite dans la region de Vyškov (Moraviae). Presse Méd. (Paris) 74: 1084. [Article in French]

Krejčí, J. 1949b. Epidemie virusových encefalitid na Vyškovsku [Outbreak of encephalitis virus in the region of Vyškov]. Lék. Listy (Brno) 4: 73-5, 112-6, 132-4. [Articles in Czech]

Křivanec, K., Kopecký, J., Tomková, E., and Grubhoffer, L. 1988. Isolation of TBE virus from the tick Ixodes hexagonus. Folia Parasit. 35: 273-6. 
Kunz, C. 2003. TBE vaccination and the Austrian experience. Vaccine 21 (Suppl 1): S50-5.

Kunz, C., and Heinz, F.X. 2003. Tick-borne encephalitis. Vaccine 21(Suppl 1): S1-2.

Labuda, M., Austyn, J.M., Žuffová, E., Kožuch, O., Fuchsberger, N., Lysý, J., and Nuttall, P.A. 1996. Importance of localized skin infection in tick-borne encephalitis virus transmission. Virology 219: 357-66.

Labuda, M., Jones, L.D., Williams, T., Danielová, V., and Nuttall, P.A. 1993. Efficient transmission of tick-borne encephalitis virus between cofeeding ticks. J. Med. Entomol. 30: 295-9.

Labuda, M., Kožuch, O., Žuffová, E., Elečková, E., Hails, R.S., and Nuttall, P.A. 1997. Tickborne encephalitis virus transmission between ticks cofeeding on specific immune natural rodent hosts. Virology 235: 138-43.

Leonova, G.N., and Maistrovskaya, O.S. 1996b. [Viremia in patients with tick-borne encephalitis and in patients with sucking ixodidae ticks]. Vopr. Virusol. 5: 224-8. [Article in Russian]

Leonova, G.N., and Maistrovskaya, O.S., and Borisevich, V.B. 1996a. [Antigenemia in subjects infected with tickborne encephalitis virus]. Vopr. Virusol. 6: 260-3. [Article in Russian]

Lindenbach, B.D., and Rice, C.M. 2003. Molecular biology of flaviviruses. Adv. Virus. Res. 59: 23-61.

Lindquist, L., and Vapalahti, O. 2008. Tick-borne encephalitis. Lancet 371: 1861-71.

Loktev, V.B., Ternovoŭ, V.A., and Netesov, S.V. 2007. [Molecular genetic characteristics of tick-borne encephalitis virus]. Vopr. Virusol. 52: 10-6. [Article in Russian]

Lu, Z., Bröker, M., and Liang, G. 2008. Tick-borne encephalitis in mainland China. Vector Borne Zoonotic Dis. 8: 713-20.

Ludolfs D, Reinholz M, Schmitz H. Highly specific detection of antibodies to tick-borne encephalitis (TBE) virus in humans using a domain III antigen and a sensitive immune complex (IC) ELISA. J Clin Virol. 2009 Jun; 45(2):125-8.

Málková, D., and Filip, O. 1968. Histological picture in the place of inoculation and in lymph nodes of mice after subcutaneous infection with tick-borne encephalitis virus. Acta Virol. 12: 355-60.

Málková, D., Mayer, V., and Vrubel, J. 1969. The significance of the regional lymphatic system in penetration of an attenuated strain of tick-borne encephalitis virus into blood of experimentally infected animals. Acta Virol. 13: 309-14.

Málková, D., Pala, F., and Šidák, Z. 1961. Cellular changes in the white cell count, regional lymph node and spleen during infection with tick-borne encephalitis virus in mice. Acta Virol. 5: 101-11.

Mandl, C.W. 2005. Steps of tick-borne encephalitis virus replication cycle that affect neuropathogenesis. Virus Res. 111: 161-74.

Mayer, V. 1966. A mutant of tick-borne encephalitis (TE) virus with lost neurovirulence for monkeys. Acta Virol. 10: 561.

Mickiene, A., Laiskonis, A., Günther, G., Vene, S., Lundkvist, A., and Lindquist, L. 2002. Tickborne encephalitis in an area of high endemicity in Lithuania: disease severity and long-term prognosis. Clin. Infect. Dis. 35: 650-8.

Molnár, E., and Fornosi, F. 1952. [Accidental laboratory infection with the Czechoslovakian strain of tick encephalitis]. Orv. Hetil. 93: 1032-3. [Article in Hungarian] 
Niedrig, M., Vaisviliene, D., Teichmann, A., Klockmann, U., and Biel, S.S. 2001. Comparison of six different commercial IgG-ELISA kits for the detection of TBEV-antibodies. J. Clin. Virol. 20: 179-82.

Nuttall, P.A., and Labuda, M. 2003. Dynamics of infection in tick vectors and at the tick-host interface. Adv. Virus Res. 60: 233-72.

Oker-Blom, N. 1956. Kumlinge disease; a meningoencephalitis occuring in the Aaland Islands. Ann. Med. Exp. Biol. Fenn. 34: 309-18.

Pattyn, S.R., and Wyler, R. 1955. Viral meningoencephalitis in Austria. IV. Virus in blood in experimental infection; attempted transmission by mosquitoes. Bull. World Health Organ. 12: 581-9.

Pavlova, B.G., Loew-Baselli, A., Fritsch, S., Poellabauer, E.M., Vartian, N., Rinke, I., and Ehrlich, H.J. 2003. Tolerability of modified tick-borne encephalitis vaccine FSMEIMMUN "NEW" in children: results of post-marketing surveillance. Vaccine 21: 7425.

Pavlovskij, E.N. 1939. [On natural focality of infectious and parasitic diseases]. Vestn. Akad. Nauk SSSR 10: 98-108. [Article in Russian]

Petri E, Gniel D, Zent O. Tick-borne encephalitis (TBE) trends in epidemiology and current and future management. Travel Med Infect Dis. 2010 Jul;8(4):233-45.

Petrishcheva, P.A., and Levkovich, E.N. 1945. [Spring-Summer encephalitis in Leningrad region. Papers of Medical Officers of Volkhov Front]. Leningrad, Russia. [Book in Russian]

Pogodina, V.V., Bochkova, N.G., and Karan', L.S., Frolova, M.P., Trukhina, A.G., Malenko, G.V., Levina, L.S., and Platonov, A.E. 2004. [Comparative analysis of virulence of the Siberian and Far-East subtypes of the tick-born encephalitis virus]. Vopr. Virusol. 49: 24-30. [Article in Russian]

Pogodina, V.V., Frolova, M.P., and Erman, B.A. 1979. [Chronic Tick-Borne Encephalitis]. Nauka, Moscow, Russia. [Book in Russian]

Pogodina, V.V., Karan', L.S., Koliasnikova, N.M., Levina, L.S., Malenko, G.V., Gamova, E.G., Lesnikova, M.V., Kiliachina, A.S., Esiunina, M.S., Bochkova, N.G., Shopenskaia, T.A., Frolova, T.V., Andaev, E.I., and Trukhina, A.G. 2007. [Evolution of tick-borne encephalitis and a problem of evolution of its causative agent]. Vopr. Virusol. 52: 1621. [Article in Russian]

Pöllabauer EM, Pavlova BG, Löw-Baselli A, Fritsch S, Prymula R, Angermayr R, Draxler W, Firth C, Bosman J, Valenta B, Harmacek P, Maritsch F, Barrett PN, Ehrlich HJ. Comparison of immunogenicity and safety between two paediatric TBE vaccines. Vaccine. 2010 Jun 23;28(29):4680-5.

Poponnikova, T.V. 2006. Specific clinical and epidemiological features of tick-borne encephalitis in Western Siberia. Int. J. Med. Microbiol. 296(Suppl 40): 59-62.

Puchhammer-Stöckl, E., Kunz, C., Mandl, C.W., and Heinz, F.X. 1995. Identification of tickborne encephalitis virus ribonucleic acid in tick suspensions and in clinical specimens by a reverse transcriptionnested polymerase chain reaction assay. Clin. Diagn. Virol. 4: 321-6.

Rampas, J., and Gallia, F. 1949. [Isolation of tick-borne encephalitis virus from ticks Ixodes ricinus]. Čas. Lék. čes. 88: 1179-80. [Article in Czech] 
Randolph, S. 2002. The changing incidence of tick-borne encephalitis in Europe. Euro Surveill 6: pii=1953. Available online: http://www.eurosurveillance.org/ViewArticle.aspx ?ArticleId=1953.

Rendi-Wagner, P. 2008. Advances in vaccination against tick-borne encephalitis. Expert Rev Vaccines 7: 589-96.

Rendi-Wagner, P., Kundi, M., Zent, O., Banzhoff, A., Jaehnig, P., Stemberger, R., Dvorak, G., Grumbeck, E., Laaber, B., and Kollaritsch, H. 2004. Immunogenicity and safety of a booster vaccination against tick-borne encephalitis more than 3 years following the last immunisation. Vaccine 23: 427-34.

Romanova, L.Iu., Gmyl, A.P., Dzhivanian, T.I., Bakhmutov, D.V., Lukashev, A.N., Gmyl, L.V., Rumyantsev, A.A., Burenkova, L.A., Lashkevich, V.A., and Karganova, G.G. 2007. Microevolution of tick-borne encephalitis virus in course of host alternation. Virology 362: 75-84.

Růžek, D., Dobler, G., and Donoso Mantke, O. 2010. Tick-borne encephalitis: pathogenesis and clinical implications. Travel Med. Infect. Dis. 8(4):223-32.

Růžek, D., Gritsun, T.S., Forrester, N.L., Gould, E.A., Kopecký, J., Golovchenko, M., Rudenko, N., and Grubhoffer, L. 2008. Mutations in the NS2B and NS3 genes affect mouse neuroinvasiveness of a Western European field strain of tick-borne encephalitis virus. Virology 374: 249-55.

Růžek, D., Salát, J., Palus, M., Gritsun, T.S., Gould, E.A., Dyková, I., Skallová, A., Jelínek, J., Kopecký, J., and Grubhoffer, L. 2009. CD8+ T-cells mediate immunopathology in tick-borne encephalitis. Virology 384: 1-6.

Růžek, D., Salát, J., Singh, S.K., Kopecký, J. 2011. Breakdown of the Blood-Brain Barrier During Tick-Borne Encephalitis in Mice Is Not Dependent on CD8 ${ }^{+}$T-cells. PLoS One, 6(5):e20472.

Růžek, D., Št'astná, H., Kopecký, J., Golovljova, I., and Grubhoffer, L. 2007. Rapid subtyping of tick-borne encephalitis virus isolates using multiplex RTPCR. J. Virol. Methods 144: 133-7.

Růžek, D., Štěrba, J., Kopecký, J., and Grubhoffer, L. 2006. The supposedly attenuated HyHK variant of highly virulent Hypr strain of tick-borne encephalitis virus is obviously a strain of Langat virus. Acta Virol. 50: 277-8.

Saksida, A., Duh, D., Lotric-Furlan, S., Strle, F., Petrovec, M., and Avsic-Zupanc, T. 2005. The importance of tick-borne encephalitis virus RNA detection for early differential diagnosis of tick-borne encephalitis. J. Clin. Virol. 33: 331-5.

Schneider, H. 1931. [Über epidemische akute „Meningitis serosa“]. Wien. Klin. Woch. 44: 3502. [Article in German]

Schultze D, Dollenmaier G, Rohner A, Guidi T, Cassinotti P. Benefit of detecting tick-borne encephalitis viremia in the first phase of illness. J. Clin. Virol. 2007; 38: 172-5.

Schwaiger M, Cassinotti P. Development of a quantitative real-time RT-PCR assay with internal control for the laboratory detection of tick borne encephalitis virus (TBEV) RNA. J. Clin. Virol. 2003; 27: 136-45.

Šenigl, F., Grubhoffer, L., and Kopecký, J. 2006. Differences in maturation of tick-borne encephalitis virus in mammalian and tick cell line. Intervirology 49: 236-48.

Shapoval, A.N. 1976. [Chronic Forms of Tick-Borne Encephalitis]. Medicina, Leningrad, Russia. [Book in Russian] 
Shapoval, A.N. 1977. [Inapparent forms of tick-borne encephalitis]. Zh. Mikrobiol. Epidemiol. Immunobiol. 5:11-7. [Article in Russian]

Simon, J., Slonim, D., and Zavadova, H. 1966. [Experimentelle Untersuchungen von klinischen und subklinischen Formen der Zeckenencephalitis an unterschiedlich empfänglichen Wirten: Mäusen, Hamstern und Affen. II. Hamster]. Acta Neuropathol. 7: 89-100. [Article in German]

Sinnecker, H. 1960. [Zeckenencephalitis in Deutschland]. Zbl. Bakt. Orig. 180: 12-8. [Article in German]

Slávik, I., Mayer, V., and Mrena, E. 1967. Morphology of purified tick-borne encephalitis virus. Acta Virol. 11: 66.

Sonnenberg, K., Niedrig, M., Steinhagen, K., Rohwäder, E., Meyer, W., Schlumberger, W., Müller-Kunert, E., and Stöcker, W. 2004. State-of-the-art serological techniques for detection of antibodies against tick-borne encephalitis virus. Int. J. Med. Microbiol. 293(Suppl 37): 148-51.

Süss, J. 2003. Epidemiology and ecology of TBE relevant to the production of effective vaccines. Vaccine 21(Suppl 1): S19-35.

Süss, J. 2008. Tick-borne encephalitis in Europe and beyond - the epidemiological situation as of 2007. Euro Surveill 13(26). pii: 18916.

Szajna, M. 1954. [Tick-borne encephalitis in Poland]. Pol. Tyg. Lek. (Wars.) 9: 1625-7. [Article in Polish]

Thiel, H.J., Collett, M.S., Gould, E.A., Heinz, F.X., Houghton, M., Meyers, G. et al. 2005. In: Fauquet CM, Mayo MA, Maniloff J, Desselberger U, Ball LA, Eds. Virus Taxonomy: Classification and Nomenclature, Eighth Report of the International Committee on the Taxonomy of Viruses. Amsterdam, Boston, Heidelberg, London, New York, Oxford, Elsevier Academic Press; pp. 981-98.

Vaptsarov, I., Turpomanov, A., Spasov, Z., Nikov, D., and Dragiev, M. 1954. [Recurrent viral meningoencephalitis in southern Bulgaria]. Surv. Med. (Sofiia) 5: 86-103. [Article in Bulgarian]

Vein, A.A., and van Emde Boas, W. 2011. Kozhevnikov epilepsy: the disease and its eponym. Epilepsia 52(2):212-8.

Voronkova, G.M., and Zakharycheva, T.A. 2007. [The condition of tick-borne infections problem in Khabarovsk region]. Bulletin SORAMN 4: 82-88. [Article in Russian]

Votiakov, V.I., Zlobin, V.I., and Mishayeva, N.P. 2002. [Tickborne encephalitis of Eurasia. Ecology, molecular epidemiology, nosology, evolution]. Nauka, Novosibirsk, Russia. [Book in Russian]

Waldvogel, K., Bossart, W., Huisman, T., Boltshauser, E., and Nadal, D. 1996. Severe tickborne encephalitis following passive immunization. Eur. J. Pediatr. 155: 775-9.

Yamshchikov, V.F., and Compans, R.W. 1993. Regulation of the late events in flavivirus protein processing and maturation. Virology 192: 38-51.

Zent, O., Banzhoff, A., Hilbert, A.K., Meriste, S., Słuzewski, W., and Wittermann Ch. 2003. Safety, immunogenicity and tolerability of a new pediatric tickborne encephalitis (TBE) vaccine, free of proteinderived stabilizer. Vaccine 21: 3584-92.

Zilber, L.A. 1939. [Spring (spring-summer) epidemical tick-borne encephalitis]. Arch. biol. Nauk 56: 9-37. [Article in Russian] 


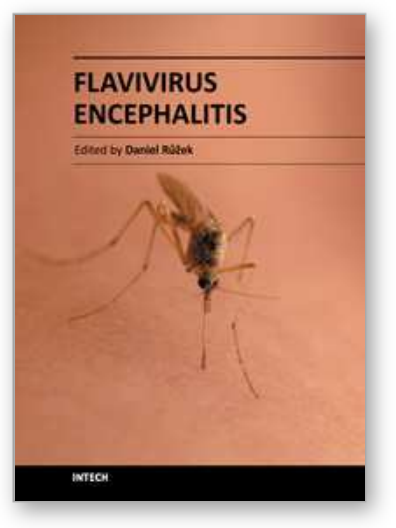

\author{
Flavivirus Encephalitis \\ Edited by Dr. Daniel Ruzek
}

ISBN 978-953-307-669-0

Hard cover, 478 pages

Publisher InTech

Published online 30, September, 2011

Published in print edition September, 2011

Encephalitis is an inflammation of the brain tissue associated with clinical evidence of brain dysfunction. The disease is of high public health importance worldwide due to its high morbidity and mortality. Flaviviruses, such as tick-borne encephalitis virus, Japanese encephalitis virus, Murray Valley encephalitis virus, or St. Louis encephalitis virus, represent important causative agents of encephalitis in humans in various parts of the world. The book Flavivirus Encephalitis provides the most recent information about selected aspects associated with encephalitic flaviviruses. The book contains chapters that cover a wide spectrum of subjects including flavivirus biology, virus-host interactions, role of vectors in disease epidemiology, neurological dengue, and West Nile encephalitis. Special attention is paid to tick-borne encephalitis and Japanese encephalitis viruses. The book uniquely combines up-to-date reviews with cutting-edge original research data, and provides a condensed source of information for clinicians, virologists, pathologists, immunologists, as well as for students of medicine or life sciences.

\title{
How to reference
}

In order to correctly reference this scholarly work, feel free to copy and paste the following:

Oliver Donoso-Mantke, Luidmila S. Karan and Daniel Růžek (2011). Tick-Borne Encephalitis Virus: A General Overview, Flavivirus Encephalitis, Dr. Daniel Ruzek (Ed.), ISBN: 978-953-307-669-0, InTech, Available from: http://www.intechopen.com/books/flavivirus-encephalitis/tick-borne-encephalitis-virus-a-general-overview

\section{INTECH}

open science | open minds

\section{InTech Europe}

University Campus STeP Ri

Slavka Krautzeka 83/A

51000 Rijeka, Croatia

Phone: +385 (51) 770447

Fax: +385 (51) 686166

www.intechopen.com

\section{InTech China}

Unit 405, Office Block, Hotel Equatorial Shanghai

No.65, Yan An Road (West), Shanghai, 200040, China 中国上海市延安西路65号上海国际贵都大饭店办公楼 405 单元 Phone: +86-21-62489820

Fax: +86-21-62489821 
(C) 2011 The Author(s). Licensee IntechOpen. This chapter is distributed under the terms of the Creative Commons Attribution-NonCommercialShareAlike-3.0 License, which permits use, distribution and reproduction for non-commercial purposes, provided the original is properly cited and derivative works building on this content are distributed under the same license. 